\title{
Trends in Cancer Research and Chemotherapy
}

\section{Editorial}

\section{Novel CAR-T cells to eliminate cancer}

\author{
Vita Golubovskaya* and Lijun Wu \\ ProMab Biotechnologies, 2600 Hilltop Drive, C346, Richmond, CA, USA
}

We are excited to start a first issue of online journal Trends in Cancer Research and Chemotherapy. The journal will be focused on all aspects of cancer research and chemotherapies.

Recently immunotherapy became very important type of therapy to decrease cancer growth. In particularly, CAR (chimeric antigen receptor) therapy [1-3] demonstrated remarkable results leading to two novel FDA-approved drugs. Cellular immunotherapy such as CAR -T cell therapy is a highly promising approach for the treatment of hematological and solid cancers [4-6]. CAR-T cell therapy is efficacious against B cell malignancies including leukemia (acute lymphoblastic leukemia (ALL), chronic lymphocytic leukemia (CLL), acute myeloid leukemia (AML), diffuse large B cell lymphoma, follicular lymphoma and mantle cell lymphoma and others [7-9]. In addition, CAR-T cells effectively eliminate solid tumor cancer [10].

The CARs contain an extracellular single-chain variable fragment $(\mathrm{scFv})$ specific for the tumor surface antigen, along with a transmembrane domain and intracellular co-stimulation and activation domains [5-7]. In clinical trials, CD19-specific CAR-T cells targeting CD19-positive hematological cancers have yielded response rates of $80-90 \%$ in acute lymphoblastic leukemia and $50-80 \%$ in refractory lymphomas [11]. In solid tumors, there are more challenges exist on the road to achieve high response rate in patients [12].

Recently we demonstrated that the addition of a FLAG (DYKDDDDK) tag to the CD19 CAR did not affect its cytotoxic function against cancer cells in vitro or in vivo [13]. In addition, the FLAG tag reduced the levels of cytokines produced by the CAR-T cells, which might be advantageous for clinical studies (for example, limiting cytokine release syndrome). The FLAG tag can be used for detection, sorting the CAR-T-positive cells and for imaging the CAR-T cells after injection into the patient. Importantly, the FLAG tag is not immunogenic in primates [14], suggesting that it can be used for human studies.

FLAG-tagged CAR-T cells are not limited to hematological cancers, but can also be used for solid cancers. We recently found that FLAGtagged CAR-T cells specific for mesothelin were as effective as nontagged mesothelin-specific CAR-T cells. As with CD19, mesothelinFLAG CAR-T cells were effectively detected with the anti-FLAG antibody.

In addition, we developed novel CD47-CAR-T cells targeting CD47 tumor antigen and demonstrated that CD47-CAR-T cells effectively killed ovarian, pancreatic, lung, melanoma cancer cell lines in vitro and blocked pancreatic xenograft tumor growth in vivo $[15,16]$. We also developed humanized CD47 CAR-T cells that will be tested in future in vivo.
Thus, novel CAR-T therapies will be developed in future against hematological and solid tumor targets.

I would like other authors to submit their novel data to our journal.

\section{References}

1. Eshhar Z, Waks T, Gross G (2014) The emergence of T-bodies/CAR T cells. Cancer J 20: 123-126. [Crossref]

2. Maus MV, June CH2 (2016) Making Better Chimeric Antigen Receptors for Adoptive T-cell Therapy. Clin Cancer Res 22: 1875-1884. [Crossref]

3. Klebanoff CA, Yamamoto TN, Restifo NP (2014) Immunotherapy: Treatment of aggressive lymphomas with anti-CD19 CAR T cells. Nat Rev Clin Oncol 11: 685-686. [Crossref]

4. Eshhar Z, Gross G (1990) Chimeric T cell receptor which incorporates the anti-tumour specificity of a monoclonal antibody with the cytolytic activity of $T$ cells: a model system for immunotherapeutical approach. Br J Cancer Suppl 10: 27-29.

5. Maus MV, Grupp SA, Porter DL, June CH (2014) Antibody-modified T cells: CARs take the front seat for hematologic malignancies. Blood 123: 2625-2635. [Crossref]

6. Porter DL, Levine BL, Kalos M, Bagg A, June $\mathrm{CH}$ (2011) Chimeric antigen receptormodified T cells in chronic lymphoid leukemia. $N$ Engl J Med 365: 725-733.

7. Portell CA, Wenzell CM, Advani AS (2013) Clinical and pharmacologic aspects of blinatumomab in the treatment of B-cell acute lymphoblastic leukemia. Clin Pharmacol 5: 5-11.

8. Jensen MC1, Riddell SR2 (2015) Designing chimeric antigen receptors to effectively and safely target tumors. Curr Opin Immunol 33: 9-15. [Crossref]

9. Grupp SA, Kalos M, Barrett D, Aplenc R, Porter DL, et al. (2013) Chimeric antigen receptor-modified T cells for acute lymphoid leukemia. N Engl J Med 368: 1509-1518.

10. Gilham DE, Debets R, Pule M, Hawkins RE, Abken H (2012) CAR-T cells and solid tumors: tuning T cells to challenge an inveterate foe. Trends Mol Med 18: 377-384. [Crossref]

11. Fesnak A, Lin C, Siegel DL, Maus MV (2016) CAR-T Cell Therapies From the Transfusion Medicine Perspective. Transfus Med Rev 30: 139-145.

12. Kakarla S, Gottschalk S (2014) CAR T cells for solid tumors: armed and ready to go? Cancer J 20: 151-155. [Crossref]

13. Berahovich R, Xu S, Zhou H, Harto H, Xu Q, et al. (2017) FLAG-tagged CD19 specific CAR-T cells eliminate CD19-bearing solid tumor cells in vitro and in vivo. Front Biosci (Landmark Ed) 22: 1644-1654.

14. Rodino-Klapac LR, Montgomery CL, Bremer WG, Shontz KM, Malik V, et al. (2010) Persistent expression of FLAG-tagged micro dystrophin in nonhuman primates following intramuscular and vascular delivery. Mol Ther 18: 109-117.

${ }^{\star}$ Correspondence to: Vita Golubovskaya, Ph.D., Director R\&D, Promab Biotechnologies, USA, Tel: phone: 510-974-0697, E-mail: vita.gol@promab.com

Key words: Military medicine, Dissociative anesthesia, Surgery, Immediacy, Expectancy

Received: April 30, 2018; Accepted: May 03, 2018; Published: May 07, 2018 
15. Golubovskaya V, Berahovich R, Zhou H, Xu S, Harto H, et al. (2017) CD47-CAR-T Cells Effectively Kill Target Cancer Cells and Block Pancreatic Tumor Growth. Cancers (Basel) 9: 10 .
16. Golubovskaya V (2017) CAR-T Cell Therapy: From the Bench to the Bedside. Cancers (Basel) 9. [Crossref]

Copyright: $\mathbb{0} 2018$ Golubovskaya V. This is an open-access article distributed under the terms of the Creative Commons Attribution License, which permits unrestricted use, distribution, and reproduction in any medium, provided the original author and source are credited. 